\title{
The Biological Investigations of a Benzoguanamine- based Nickel Complex and Its Application as a Capable Nano-catalyst for the Synthesis of Benzimidazoles
}

\section{Sajjad Oliaee}

Bu Ali Sina University Faculty of Chemistry

Davood Habibi ( $\sim$ davood.habibi@gmail.com )

Bu Ali Sina University Faculty of Chemistry https://orcid.org/0000-0002-2386-8502

Somayyeh Heydari

Bu Ali Sina University Faculty of Chemistry

Roya Karamian

Bu Ali Sina University Faculty of Science

Nika Ranjbar

University of Tehran College of Science

\section{Research Article}

Keywords: Ni-complex, benzoguanamine, o-phenylenediamine, aldehydes, benzimidazoles, biological activities

Posted Date: September 30th, 2021

DOI: https://doi.org/10.21203/rs.3.rs-908854/v1

License: (c) (i) This work is licensed under a Creative Commons Attribution 4.0 International License.

Read Full License 


\section{Abstract}

The benzoguanamine-based nickel complex was prepared, characterized by several methods and its biological (anti-bacterial, anti-cancer and anti-oxidant) activities were investigated. Also, the benzoguanamine-based nickel complex was used as a capable heterogeneous nano-catalyst for the synthesis of diverse 2-phenyl-1 $H$-benzo[d]imidazoles from the reaction of $o$-phenylenediamine (PhenDA) with various aldehydes in chloroform at reflux conditions.

\section{Introduction}

Benzimidazoles are known nitrogen-containing compounds which show anthelminthic [1], anti-allergic [2], anti-cancer [3-6], anti-diabetic [7], anti-fungal [8], anti-inflammatory [9], anti-malarial [10], anti-microbial [11-14], anti-parasitic [15], anti-tubercular [16], and anti-viral activities [17,18]. Also, they are potent molecules to be used in pharmaceutical industry [19], inhibition of HIV-1 reverse transcriptase [20], topoisomerase-I inhibition and cytotoxicity [21], treatment of Parkinson disease [22], asymmetric catalysis [23], chemo-sensing [24], corrosion science [25,26], crystal engineering [27], and fluorescence [28].

Due to the biological and industrial importance of benzimidazole compounds, several various methods have been used for their synthesis. For example, from the reaction of aromatic and heteroaromatic 2nitroamines by formic acid, iron powder and $\mathrm{NH}_{4} \mathrm{Cl}$ [29], the use of various o-phenylenediamines and $\mathrm{N}-$ substituted formamides in the presence of zinc and poly (methylhydrosiloxane) [30], the reaction of $o$ iodoanilines or electron-rich aromatic amines with $\mathrm{K}_{2} \mathrm{~S}$ and DMSO [31], the reaction of aryl amines and aldehydes with azides [32], the reaction of anilines, primary alkyl amines with sodium azide in the presence of $\mathrm{Cu}$ and t-butyl hydroperoxide [33], the reaction of phenylenediamines and aldehydes by cobalt nano-composite [34], the reaction of aromatic diamine with primary alcohols by $\mathrm{Mn}(\mathrm{I})$ complex [35], the condensation reaction of simple o-phenylenediamines and a broad range of aldehydes by molecular iodine under basic conditions [36], the reaction of $o$-phenylenediamines and primary amines by o-quinone catalyst [37], a solvent- and catalyst-free reaction of alkylamines and $o$ hydroxy/amino/mercaptan anilines in the presence of elemental sulfur as traceless oxidizing agent [38], the reaction of $o$-nitroanilines with alcohols by sodium sulfide and iron(III) chloride hexahydrate [39], a solvent-free cobalt- or iron-catalyzed reaction of 2-nitroanilines with benzylamines [40], the Brønsted acid catalyzed reactions of 2-aminothiophenols and anilines with $\beta$-diketones [41], the reaction of $O$ substituted anilines with functionalized orthoesters by Lewis acid [42], the oxone mediated reaction of 2aminobenzylamines with aromatic, hetero-aromatic, and aliphatic aldehydes [43], a one-pot multicomponent synthesis of imidazo[1,2-a]pyridine derivatives by the use of pyridin-2-amines, aldehydes, and terminal alkynes in the presence of a catalytic amount of silica-supported iron oxide nanoparticles in refluxing EtOH in good-to-excellent yields [44], the syntheses of multifunctional 1,2disubstituted benzimid-azoles from the reaction of 1,2-diamines and aldehydes or ketones by the chitosan-supported $\mathrm{Fe}_{3} \mathrm{O}_{4}$ in ethanol at ambient temperature [45], the synthesis of tetraheterocyclic benzimid-azolo[2,3-b]quinazolinones via the one-pot multicomponent condensation reaction of 2-amino- 
benzimidazole, dimedone, and various aldehydes by the use of $\mathrm{Fe}_{3} \mathrm{O}_{4} @$ chitosan [46], the synthesis of benzimidazoles from the condensation reaction of benzaldehydes with $o$-phenylenediamine by the citric acid functionalized graphene oxide nanocomposite [47] and the synthesis of various benzimidazoloquinazolinones under mild reaction conditions by a graphene oxide-based magnetite composite nanocatalyst [48].

In recent years, the use of heterogeneous catalysts and their utility in chemical reactions has been the focus of attention, since they have advantages such as recyclability and reusability, easy separation and environmental friendliness [49-54]. That is why the design and preparation of novel heterogeneous catalysts and their use are of particular importance $[55,56]$.

To extend our new vision on the topic of the design, synthesis and applications of knowledge-based nano magnetic recyclable and reusable heterogeneous catalytic systems, we would like to report preparation of the Ni-supported nano-catalyst via synthesis of the $\mathrm{Fe}_{3} \mathrm{O}_{4}$ magnetic nanoparticles, its coating with TEOS, functionalization with CPTMS and benzo-guanamine ligand and complexation with nickel nitrate ( $\left.\mathrm{Fe}_{3} \mathrm{O}_{4} @ \mathrm{SiO}_{2} @ \mathrm{CPTMS} @ B G A @ N i\right)($ Scheme 1).

Then, the magnetic Ni-supported complex was used as an efficient heterogeneous nano-catalyst for the synthesis of diverse benzimidazoles (Scheme 2).

\section{Materials And Methods}

All reagents were purchased from the Merck and Aldrich chemical companies and used without further purification. Analytical thin-layer chromatography (TLC) was conducted on pre-coated TLC plates; silica gel 60 F-254 [E. Merck, Darmstadt, Germany]. The NMR spectra were recorded on a Bruker Avance DRX $250 \mathrm{MHz}$ instruments in $\mathrm{CDCl}_{3}$. The chemical shifts are reported in parts per million (ppm) relative to TMS as an internal standard and $J$ values are given in hertz. FT-IR $(\mathrm{KBr})$ spectra were recorded on an Alpha Perkin Elmer spectro-photometer. Melting points were taken in open capillary tubes with a Stuart melting point apparatus and are uncorrected. The ICP measurements for the metal content evaluation were performed using a Perkin-Elmer ICP/6500.

\section{Preparation of the Ni-supported nano-catalyst}

The new Ni-supported nano-catalyst was synthesized in the following five sequential stages.

\section{The first stage: preparation of the $\mathrm{Fe}_{3} \mathrm{O}_{4}$ magnetic nanoparticles}

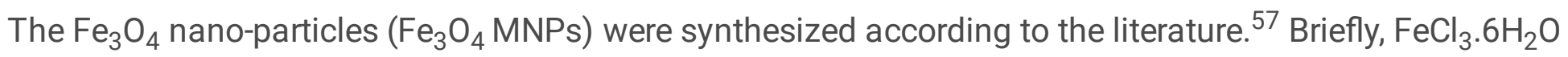
(11.44 g, 42.39 mmole) and $\mathrm{FeCl}_{2} \cdot 4 \mathrm{H}_{2} \mathrm{O}(4.3 \mathrm{~g}, 21.62$ mmole) were dissolved in water (100 mL) and stirred for $30 \mathrm{~min}$ at $80{ }^{\circ} \mathrm{C}$. Then, $\mathrm{NH}_{3} \cdot \mathrm{H}_{2} \mathrm{O} 37 \%$ was added dropwise to the mixture with vigorous stirring, the $\mathrm{pH}$ of the reaction set to 10 and the reaction held further for $30 \mathrm{~min}$. A black precipitate filtered, washed with water and vacuum dried. 


\section{The second stage: coating of $\mathrm{Fe}_{3} \mathrm{O}_{4}$ MNPs with TEOS}

The coated $\mathrm{Fe}_{3} \mathrm{O}_{4}$ MNPs $\left(\mathrm{Fe}_{3} \mathrm{O}_{4} @ \mathrm{SiO}_{2}\right)$ were prepared by previous reported method [58]. Briefly, $\mathrm{Fe}_{3} \mathrm{O}_{4}$ MNPs were dispersed into a mixture of ethanol-water under ultrasound irradiation. Then, $\mathrm{NH}_{3} \cdot \mathrm{H}_{2} \mathrm{O}(3.0$ $\mathrm{mL}$ ) and tetraethyl ortho silicate (TEOS, $2.0 \mathrm{~mL}, 9.024 \mathrm{mmole}$ ) were added dropwise to the reaction mixture. $\mathrm{Fe}_{3} \mathrm{O}_{4} @ \mathrm{SiO}_{2}$ were obtained, washed with water and ethanol for several times, and dried under vacuum.

\section{The third stage: functionalization of $\mathrm{Fe}_{3} \mathrm{O}_{4} / \mathrm{SiO}_{2}$ with the CPTMS ligand}

Functionalization of $\mathrm{Fe}_{3} \mathrm{O}_{4} @ \mathrm{SiO}_{2}$ was carried out with 3-chloropropyltrimethoxysilane (CPTMS). So, CPTMS (1.0 mL, 5.0 mmole), $\mathrm{Fe}_{3} \mathrm{O}_{4} @ \mathrm{SiO}_{2}(1.0 \mathrm{~g})$ and anhydrous toluene $(100 \mathrm{~mL})$ were mixed and stirred for $18 \mathrm{~h}$ at $60^{\circ} \mathrm{C}$. Then, $\mathrm{Fe}_{3} \mathrm{O}_{4} @ \mathrm{SiO}_{2} @ \mathrm{CPTMS}$ was separated with a super magnet, washed with toluene and dried under vacuum.

\section{The fourth stage: further functionalization with the BGA ligand}

Further functionalization of $\mathrm{Fe}_{3} \mathrm{O}_{4} @ \mathrm{SiO}_{2} @ \mathrm{CPTMS}$ was taken place by the mixing of BGA $(0.93 \mathrm{~g}, 5.0$ mmole), $\mathrm{K}_{2} \mathrm{CO}_{3}$ (414 mg, $\left.3.0 \mathrm{mmole}\right)$, toluene $(50 \mathrm{~mL})$ and $\mathrm{Fe}_{3} \mathrm{O}_{4} @ \mathrm{SiO}_{2} @ \mathrm{CPTMS}(0.1 \mathrm{~g})$ and refluxed for $12 \mathrm{~h}$. The precipitate $\left(\mathrm{Fe}_{3} \mathrm{O}_{4} @ \mathrm{SiO}_{2} @ \mathrm{CPTMS} @ \mathrm{BGA}\right)$ was separated with super magnet, washed several times with ethanol/water and dried in vacuum.

\section{The fifth stage: complexation of $\mathrm{Fe}_{3} \mathrm{O}_{4} / \mathrm{SiO}_{2} / \mathrm{CPTMS} / \mathrm{BGA}$ with $\mathrm{Ni}\left(\mathrm{NO}_{3}\right)_{2}$}

The complexation of $\mathrm{Fe}_{3} \mathrm{O}_{4} @ \mathrm{SiO}_{2} @ C P T M S @ B G A$ was accomplished with $\mathrm{Ni}\left(\mathrm{NO}_{3}\right)_{2}$. So, $\mathrm{Fe}_{3} \mathrm{O}_{4} @ \mathrm{SiO}_{2} @ \mathrm{CPTMS} @ B G A(0.2 \mathrm{~g})$ and $\mathrm{Ni}\left(\mathrm{NO}_{3}\right)_{2} \cdot 6 \mathrm{H}_{2} \mathrm{O}(1.45 \mathrm{~g}, 5.0 \mathrm{mmole})$ was stirred in toluene (100 $\mathrm{ML}$ ) under nitrogen atmosphere at $70^{\circ} \mathrm{C}$ and completion of the reaction monitored with TLC. Then, the obtained Ni-supported nano-catalyst $\left(\mathrm{Fe}_{3} \mathrm{O}_{4} @ \mathrm{SiO}_{2} @ \mathrm{CPTMS} @ B G A @ \mathrm{Ni}\right)$ was separated by super magnet, washed with ethanol and air-dried.

\section{General procedure for the synthesis of benzimidazoles by the Ni-supported nano-catalyst}

A solution of PhenDA (108 mg, 1.0 mmole), aromatic aldehyde (1.0 mmole), $\mathrm{CHCl}_{3}(3 \mathrm{~mL})$ and the $\mathrm{Ni}$ supported nano-catalyst $(20 \mathrm{mg}$ ) were mixed and heated with stirring under reflux condition for 10-60 min depending on the type of aldehyde. The progress of the reaction was monitored by TLC (mobile phase: $\mathrm{n}$ hexane/EtOAc/methanol). After completion of the reaction, the reaction mixture was allowed to cool to it and the Ni-supported nano-catalyst was separated using a super magnet. After solvent evaporation, the pure products were obtained by recrystallization in ethanol.

\section{Selected spectral data}

2-Phenyl-1H-benzo[d]imidazole (3a) 
IR $\left(\mathrm{KBr}, \mathrm{cm}^{-1}\right): 1621(\mathrm{C}=\mathrm{N}), 3440(\mathrm{NH}) ;{ }^{1} \mathrm{H}$ NMR $\left(\mathrm{DMSO}-d_{6}, 250 \mathrm{MHz}\right): \delta_{\mathrm{H}}(\mathrm{ppm})=12.93(\mathrm{H}$ of NH$), 8.5-$ 6.87 (aromatic hydrogens); ${ }^{13} \mathrm{C}$ NMR (DMSO- $\left.d_{6}, 62.5 \mathrm{MHz}\right): \delta_{\mathrm{C}}(\mathrm{ppm})=122.1,126.4,128.4,128.9,129.2$, $129.8,130.1,151.2$.

\section{2-(2-Hydroxyphenyl)-1H-benzo[d]imidazole (3b)}

IR $\left(\mathrm{KBr}, \mathrm{cm}^{-1}\right): 1600(\mathrm{C}=\mathrm{N}), 3247(\mathrm{OH}, \mathrm{NH}) .{ }^{1} \mathrm{H} \mathrm{NMR}\left(250 \mathrm{MHz}, \mathrm{CDCl}_{3}\right): \delta_{\mathrm{H}}(\mathrm{ppm})=13(\mathrm{H}$ of NH$), 9.27(\mathrm{H}$ of $\left.\mathrm{H}_{2} \mathrm{O}\right)$, 8.86-6.56 (aromatic hydrogens); ${ }^{13} \mathrm{C} \mathrm{NMR}\left(62.5 \mathrm{MHz}, \mathrm{CDCl}_{3}\right): \delta_{\mathrm{C}}(\mathrm{ppm})=111.4,112.5,117.2,117.6$, $119.07,122.3,123.2,126.1,131.6,151.6,157.9$.

\section{2-(4-Hydroxyphenyl)-1H-benzo[d]imidazole (3d)}

IR $\left(\mathrm{KBr}, \mathrm{cm}^{-1}\right): 1605(\mathrm{C}=\mathrm{N}), 3251(\mathrm{OH}, \mathrm{NH}) ;{ }^{1} \mathrm{H}$ NMR (DMSO- $\left.d_{6}, 250 \mathrm{MHz}\right): \delta_{\mathrm{H}}(\mathrm{ppm})=12.65(\mathrm{H}$ of NH$)$, $10.07\left(\mathrm{H}\right.$ of $\left.\mathrm{H}_{2} \mathrm{O}\right), 8.32-6.67$ (aromatic hydrogens); ${ }^{13} \mathrm{C}$ NMR (DMSO- $\left.d_{6}, 62.5 \mathrm{MHz}\right): \delta_{\mathrm{C}}(\mathrm{ppm})=115.6$, $121.0,121.6,128.1,151.7,159.1$.

\section{2-(4-Methoxyphenyl)-1H-benzo[d]imidazole (3e)}

IR $\left(\mathrm{KBr}, \mathrm{cm}^{-1}\right): 1610(\mathrm{C}=\mathrm{N}), 3420(\mathrm{NH}) ;{ }^{1} \mathrm{H}$ NMR $\left(\mathrm{DMSO}^{-} d_{6}, 250 \mathrm{MHz}\right): \delta_{\mathrm{H}}(\mathrm{ppm})=12.76(\mathrm{H}$ of NH$), 8.2-7$ (aromatic hydrogens), 3.9-3.4 (Hs of $\left.\mathrm{OCH}_{3}\right) ;{ }^{13} \mathrm{C}$ NMR (DMSO- $\left.d_{6}, 62.5 \mathrm{MHz}\right): \delta_{\mathrm{C}}(\mathrm{ppm})=110.9,114.3$, $116.4,121.5,121.9,122.5,127.9,151.3,160.5$.

\section{2-(4-Chlorophenyl)-1H-benzo[d]imidazole (3f)}

IR $\left(\mathrm{KBr}, \mathrm{cm}^{-1}\right): 1600(\mathrm{C}=\mathrm{N}), 3440(\mathrm{NH}) ;{ }^{1} \mathrm{H}$ NMR $\left(\mathrm{DMSO}^{-} d_{6}, 250 \mathrm{MHz}\right): \delta_{\mathrm{H}}(\mathrm{ppm})=12.98(\mathrm{H}$ of NH$), 8.22-$ 6.07 (aromatic hydrogens); ${ }^{13} \mathrm{C}$ NMR (DMSO- $\left.d_{6}, 62.5 \mathrm{MHz}\right): \delta_{\mathrm{C}}(\mathrm{ppm})=111.4,116.8,121.6,122.7,128.0$, $129.0,134.4,150.0$.

\section{Results}

\section{Synthesis of the Ni-supported nano-catalyst}

The Ni-supported nanoparticle catalyst was obtained via synthesis of the $\mathrm{Fe}_{3} \mathrm{O}_{4}$ magnetic nanoparticles. In order to prevent agglomeration of magnetic nanoparticles, the particles are coated with TEOS. This covering stabilizes the magnetite nanoparticles in two various ways. On the one hand, is by shielding the magnetic dipole interaction with the silica shell. On the other hand, the silica nanoparticles are negatively charged. Therefore, the silica covering enhances the coulomb repulsion. Next step is the magnetic nanoparticles functionalization with CPTMS and BGA ligand, and then complexation with $\mathrm{Ni}\left(\mathrm{NO}_{3}\right)_{2} \cdot 6 \mathrm{H}_{2} \mathrm{O}$.

\section{Characterization of the Ni-supported nano-catalyst}


Formation of the Ni-supported nano-catalyst was verified by the inductively coupled plasma (ICP), FT-IR, X-ray diffraction (XRD), dispersive X-ray spectroscopy (EDX), scanning electron microscope (SEM), transmission electron microscope (TEM), thermo-gravimetric-differential thermal analysis (TGA-DTA), vibrating sample magnetometer (VSM) and BET (Brunauer-Emmett-Teller) measurements.

\section{Characterization of the Ni-supported nano-catalyst by ICP}

The ICP analysis of the catalyst showed that the Ni content of $\mathrm{Fe}_{3} \mathrm{O}_{4} @ \mathrm{SiO}_{2} @ \mathrm{CPTMS} @ \mathrm{BGA} @ \mathrm{Ni}$ is about $49.7 \%$.

\section{Characterization of the Ni-supported nano-catalyst by FT-IR}

Figure 1 presents the four FT-IR spectra of A: $\mathrm{Fe}_{3} \mathrm{O}_{4} @ \mathrm{SiO}_{2}, \mathrm{~B}: \mathrm{Fe}_{3} \mathrm{O}_{4} @ \mathrm{SiO}_{2} @ \mathrm{CPTMS}, \mathrm{C}$ :

$\mathrm{Fe}_{3} \mathrm{O}_{4} @ S i \mathrm{O}_{2} @ \mathrm{CPTMS} @ B G A$ and D: $\mathrm{Fe}_{3} \mathrm{O}_{4} @ \mathrm{SiO}_{2} @ \mathrm{CPTMS} @ B G A @ N i . C u r v e$ A displays two basic characteristic peaks at approximately about 583 and $1091 \mathrm{~cm}^{-1}$ which are attributed to the presence of the $\mathrm{Fe}-\mathrm{O}$ and $\mathrm{Si}-\mathrm{O}$ stretching vibrations, respectively to indicate the silica coated magnetite nanoparticles. Curve $\mathbf{B}$ shows a new peak at about $636 \mathrm{~cm}^{-1}$ indicating presence of the $\mathrm{C}-\mathrm{Cl}$ bond. Curve $\mathbf{C}$ shows three new peaks at 1416,1674 and $3380 \mathrm{~cm}^{-1}$ which respectively are attributed to the $\mathrm{C}-\mathrm{C}, \mathrm{C}=\mathrm{N}$ and $\mathrm{N}-\mathrm{H}$ bonds, to refer to the BGA ligand in $\mathrm{Fe}_{3} \mathrm{O}_{4} @ \mathrm{SiO}_{2} @ \mathrm{CPTMS} @ B G A$. And finally, the curve $\mathbf{D}$ shows shifts from 3380 to 3512 and from 1674 to $1515 \mathrm{~cm}^{-1}$ which are related to the new interactions of nickel with the nitrogencontaining ligand. Consequently, comparison of the IR spectra confirms the successful stages of the Nisupported nano-catalyst.

\section{Characterization of the Ni-supported nano-catalyst by XRD}

Figure 2 shows the XRD patterns of $\mathbf{A}\left(\mathrm{Fe}_{3} \mathrm{O}_{4} @ \mathrm{SiO}_{2}\right.$, black), $\mathbf{B}\left(\mathrm{Fe}_{3} \mathrm{O}_{4} @ \mathrm{SiO}_{2} @ \mathrm{CPTMS}\right.$, green), $\mathbf{C}$ ( $\mathrm{Fe}_{3} \mathrm{O}_{4} @ \mathrm{SiO}_{2} @ C P T M S @ B G A$, blue $)$ and $\mathbf{D}\left(\mathrm{Fe}_{3} \mathrm{O}_{4} @ \mathrm{SiO}_{2} @ C P T M S @ B G A @ N i\right.$, purple).The XRD pattern exhibited peaks at about $2 \theta=18.5^{\circ}, 30.4^{\circ}, 35.7^{\circ}, 43.5^{\circ}, 53,8^{\circ}, 57.6^{\circ}, 63^{\circ}$ and $74.7^{\circ}$ confirm the spinal structure of $\mathrm{Fe}_{3} \mathrm{O}_{4} \mathrm{MNPs}$. Appearance of the new peaks at $2 \theta=12.2^{\circ}, 19.2^{\circ}, 23.7^{\circ}, 33.8^{\circ}, 38^{\circ}, 41^{\circ}, 46.7^{\circ}$ and $60^{\circ}$ are attributed to the Ni species.

\section{Characterization of the Ni-supported nano-catalyst by EDX}

Figure 3 shows the EDX analysis of the Ni-supported nano-catalyst and presence of the anticipated elements in its structure, namely N (3.34 \%), O (22.41 \%), Si (2.99 \%), Fe (11.33\%) and Ni (28.53 \%).

\section{Characterization of the Ni-supported nano-catalyst by SEM}

For the investigation of the size and surface morphology of the newly prepared catalyst, SEM images were obtained as shown in Figure 4. According to these images, the sizes of the Ni-supported nanocatalyst particles are in the nanometer ranges (between 31.7-35.6 nm).

\section{Characterization of the Ni-supported nano-catalyst by the SEM Mapping Images}


Also, the SEM elemental-mapping images presented in Figure 5 confirm the elemental composition of the synthesized catalyst and display a nice distribution of elements on the catalyst surface.

\section{Characterization of the Ni-supported nano-catalyst by TGA-DTA}

In order to investigate the thermal stability of the Ni-supported nano-catalyst, the TGA-DTA analysis was conducted and the obtained curve is illustrated in Figure 6 . The thermo gravimetric analysis curve show the three mass losses of the organic materials as they decompose upon heating. The weight loss beginning at about $85^{\circ} \mathrm{C}$ could be related to the loss of water molecules, the weight loss at about $220^{\circ} \mathrm{C}$ could be attributed to the decomposition of complex, and the weight loss at about $380^{\circ} \mathrm{C}$ could be attributed to the decomposition of the BGA ligand.

\section{Characterization of the Ni-supported nano-catalyst by VSM}

The VSM analyses of (A) $\mathrm{Fe}_{3} \mathrm{O}_{4} @ \mathrm{SiO}_{2}$, (B) $\mathrm{Fe}_{3} \mathrm{O}_{4} @ \mathrm{SiO}_{2} @ \mathrm{CPTMS},(\mathbf{C}) \mathrm{Fe}_{3} \mathrm{O}_{4} @ \mathrm{SiO}_{2} @ \mathrm{CPTMS}_{2} @ \mathrm{BG}$ and (D) the Ni-supported nano-catalyst $\left(\mathrm{Fe}_{3} \mathrm{O}_{4} @ \mathrm{SiO}_{2} @ \mathrm{CPTMS} @ \mathrm{BGA} @ \mathrm{Ni}\right)$ were investigated in order to demonstrate their magnetic behaviors (Figure 7). As can be seen, all four compounds have magnetic properties; however, magnetization of $\mathbf{B}(43.8 \mathrm{emu} / \mathrm{g}), \mathbf{C}(40.7 \mathrm{emu} / \mathrm{g})$ and $\mathbf{D}(4.7 \mathrm{emu} / \mathrm{g})$ were decreased to some extent in comparison with $\mathbf{A}(68.4 \mathrm{emu} / \mathrm{g})$. This can be explained by the reduction in the dipoledipole interactions between the magnetic nanoparticles after their coating with $\mathrm{SiO}_{2}$, functionalization with both the CPTMS and BGA ligands and the complexation with $\mathrm{Ni}\left(\mathrm{NO}_{3}\right)_{2}$ which cause the more coating of $\mathrm{Fe}_{3} \mathrm{O}_{4}$ MNPs.

\section{Characterization of the Ni-supported complex by BET}

To obtain the specific surface area, the total volume of the pores and the mean pore diameter of the Nisupported complex, the nitrogen adsorption (uptake) and desorption analysis was performed at 77 Kelvin and Table 1 shows the results of the Brunauer-Emmett-Teller (BET) measurements.

Table 1 Results of the BET measurements of the Ni-supported complex

\begin{tabular}{|ll|}
\hline Parameter & value \\
\hline $\mathrm{a}_{\mathrm{s}}\left(\mathrm{m}^{2} / \mathrm{g}\right)$ & 15.885 \\
\hline $\mathrm{V}_{\mathrm{m}}\left(\mathrm{cm}^{3} / \mathrm{g}\right)$ & 3.65 \\
\hline Total pore volume & 0.1275 \\
\hline Mean pore diameter & 32.116 \\
\hline
\end{tabular}

The Figure 8 is a type III curve and indicates the absence of the hysteresis.

The Figure 9 is the BJH adsorption curve of the Ni-supported complex indicating that the sizes of pores are approximately between 5 and $85 \mathrm{~nm}$. 


\section{Optimization of the reaction conditions}

After confirmation of the new prepared Ni-supported nano-catalyst, the catalyst capability was investigated for the synthesis of diverse benzimidazoles. To achieve this goal and to find the optimal reaction conditions, the reaction of benzaldehyde and PhenDA was chosen as a model reaction. The obtained data in various temperatures, amounts of the catalyst and solvents are summarized in Table 2. The best result is obtained when the reaction is performed in the presence of $20 \mathrm{mg}$ of the Ni-supported nano-catalyst in $\mathrm{CHCl}_{3}$ at reflux condition (entry 4).

Table 2 Optimization of the reaction conditions for the synthesis of 2-phenyl-1H-benzo[d]imidazole

\begin{tabular}{|c|c|c|c|c|c|}
\hline Entry & Solvent & Temp. $\left({ }^{\circ} \mathrm{C}\right)$ & Catal. amount (mg) & Time (min) & Yield (\%) \\
\hline 1 & $\mathrm{C}_{2} \mathrm{H}_{5} \mathrm{OH}$ & room temp & 10 & 180 & 83 \\
\hline 2 & $\mathrm{C}_{2} \mathrm{H}_{5} \mathrm{OH}$ & reflux & 10 & 60 & 85 \\
\hline 3 & $\mathrm{CHCl}_{3}$ & reflux & 10 & 40 & 82 \\
\hline 4 & $\mathrm{CHCl}_{3}$ & reflux & 20 & 30 & 95 \\
\hline 5 & $\mathrm{CHCl}_{3}$ & room temp & 20 & 120 & 84 \\
\hline 6 & $\mathrm{CHCl}_{3}$ & reflux & no catalyst & 120 & Trace \\
\hline 7 & n-Hexane & reflux & 20 & 80 & 70 \\
\hline 8 & $\mathrm{CH}_{3} \mathrm{CN}$ & reflux & 20 & 75 & 65 \\
\hline 9 & Toluene & reflux & 20 & 90 & 76 \\
\hline
\end{tabular}

\section{Synthesis of diverse benzimidazoles}

Based on the obtained results and using the optimized model reaction, the synthesis of diverse benzimidazoles (3a-j) were carried out from the reaction of PhenDA with aromatic aldehydes (2a-j) in $\mathrm{CHCl}_{3}$ by the Ni-supported nano-catalyst in reflux conditions (Table 3).

\section{Proposed mechanism for the synthesis of diverse benzimidazoles}

According to our suggested mechanism (Scheme 3), the withdrawing groups usually facilitate the reaction rates in the nucleophilic substitution reactions. They pull out the electron density of the electrophilic centers inductively or by resonance, so the electrophilic centers will become more positive, therefore the nucleophilic attack will become easier.

\section{Reusability of the Ni-supported nano-catalyst}


In another study, recyclability and reusability of the magnetic Ni-supported nano-catalyst was confirmed on the condensation of benzaldehyde and PhenDA for five runs under the optimized reaction conditions. At the end of each run, in order to dissolve and extract the desired product and unreacted starting materials and after removing the solvent, ethanol was added to the reaction mixture and heated. Thereafter, by using an external super magnet the catalyst was separated from the reaction mixture, frequently washed with ethanol, dried and reused in the next run. As illustrated in Figure 10, catalyst activity investigated is preserved after five consecutive cycles without any significant decrease in yield and reaction time.

\section{Comparison of the catalyst activities}

Table 4 shows the comparison of the previous methods (entries 1-10) used for the synthesis of benzimidazoles with our proposed method (entry 11). In general, the disadvantages of the previous methods are: formation of by-products and impurities, tedious work-up, long reaction times and low yields, while our proposed method does not have any mentioned disadvantages, and is easy, applicable and reusable with good to high yields.

Table 4 Comparison of different methods for the synthesis of benzimidazoles.

\begin{tabular}{|c|c|c|c|c|c|}
\hline Entry & Catalyst & Subject & Time (h) & Yield (\%) & Ref. \\
\hline 1 & Glycerol & Synthesis of benzimidazoles & $2-3$ & $70-85$ & [18] \\
\hline 2 & $\mathrm{AcOH} / \mathrm{O}_{2}$ & Synthesis of benzimidazoles & $0.33-1$ & $52-92$ & [19] \\
\hline 3 & $\mathrm{Na}_{2} \mathrm{~S}_{2} \mathrm{O}_{5}$ & Synthesis of benzimidazoles & $16-20$ & $43-73$ & [20] \\
\hline 4 & {$[\mathrm{Msim}] \mathrm{Cl}$} & Synthesis of benzimidazoles & $6-20$ & $79-95$ & [21] \\
\hline 5 & $\mathrm{H}_{2} \mathrm{~N}-\mathrm{SO}_{3} \mathrm{H}$ & Synthesis of benzimidazoles & 1 & $35-69$ & [22] \\
\hline 6 & $\mathrm{Me}_{2} \mathrm{~S}^{+} \mathrm{BrBr}^{-}$ & Synthesis of benzimidazoles & $4-8$ & $72-91$ & [23] \\
\hline 7 & $\mathrm{KHSO}_{4}$ & Synthesis of benzimidazoles & Up to 2 & $81-87$ & [24] \\
\hline 8 & zeolite & Synthesis of benzimidazoles & 1 & $75-94$ & [25] \\
\hline 9 & (ENPFSA) & Synthesis of benzimidazoles & $3-4$ & $70-90$ & [26] \\
\hline 10 & $\mathrm{Cu}_{2} \mathrm{O}$ & Synthesis of benzimidazoles & 16 & $40-76$ & [27] \\
\hline 11 & Our Method & $\mathrm{Fe}_{3} \mathrm{O}_{4} @ \mathrm{SiO}_{2} @ \mathrm{CPTMS} @ \mathrm{BGA} @ \mathrm{Ni}$ & $0.5-1$ & $87-95$ & - \\
\hline
\end{tabular}

\section{Biological activities}

\section{Antioxidant activity}


The electron donation ability of the complexes was evaluated by bleaching of the purple-colored methanol solution of DPPH (2,2-diphenyl-1-picrylhydrazyl). Briefly, $180 \mu \mathrm{l}$ of $0.3 \mu \mathrm{M}$ DPPH solution and 20 $\mu \mathrm{l}$ of the synthesized complexes at different concentrations were added in a 96 well microplate, and then the samples were incubated for $30 \mathrm{~min}$ at $25^{\circ} \mathrm{C}$ in the dark. The reduction process of free radicals was investigated by measuring the absorbance at $517 \mathrm{~nm}$. Ascorbic acid was used as a positive control, while the DPPH-methanol mixture without the synthesized compounds was used as the blank control [59]. The percentage inhibition of DPPH radical $(I)$ was calculated using the formula: \%l=[1( $A_{\text {sample }}$

$\left.\left.A_{\text {blank }}\right) / A_{\text {control }}\right] \times 100$, where, $A_{\text {sample }}$ is the absorbance of chemicals/ ascorbic acid and $A_{\text {blank }}$ is the absorbance of the reaction mixture containing sample and methanol and $A_{\text {control }}$ is the absorbance of the control sample containing DPPH and methanol. The antioxidant activity was expressed as $\mathrm{IC}_{50}$ value, which is defined as the amount of antioxidant that is required to decrease the initial DPPH concentration by $50 \%[60]$.

\section{Evaluation of the antibacterial activity}

For all the experiments one gram-positive and one gram-negative bacterium were used as Staphylococcus aureus (ATCC 33591), Escherichia coli (ATCC 35218). These strains were kept frozen at $-80{ }^{\circ} \mathrm{C}$ in appropriate media with $15 \%$ of glycerol.

Minimum inhibitory concentration (MIC) determined by serial broth dilution method [60]. Stock solutions of the synthesized compounds were prepared by dissolving dry compounds in solvent to a final concentration of $10 \mathrm{mg} / \mathrm{ml}$. The serial dilutions from the stock solution were made ranging from 5 to 0.30 $\mathrm{mg} / \mathrm{ml}$ using Mueller-Hinton broth media (Abcam, UK) in 96-well microplates. A bacterial inoculum was prepared with turbidity equivalent to a $0.5 \mathrm{McF}$ arland standard. The bacterial suspension containing almost $1.5 \times 10^{8} \mathrm{CFU} / \mathrm{ml}$ was prepared from a $24 \mathrm{~h}$ culture plate. Serial dilutions to get the final concentration ranging from 0.3 to $5 \mathrm{mg} / \mathrm{ml}$ of chemical compounds in MHB were prepared in a 96-well plate in a volume of $100 \mu \mathrm{l}$. Then, $100 \mu \mathrm{l}$ of bacterial suspension was inoculated into each well. A sterility control well and a growth control well were also studied for each strain. To determine the sensitivity of the microorganisms, ampicillin was conducted as a positive control at a starting concentration of 0.10 $\mathrm{mg} / \mathrm{ml}$ in sterile water. A negative control experiment was conducted using only DMSO. The microtiter plates were incubated at $37^{\circ} \mathrm{C}$ for $18 \mathrm{~h}$, and the MIC values were visually determined by a microplate reader at $620 \mathrm{~nm}$. The lowest concentration of each chemical compound displaying no visible growth was recorded as MIC. MIC values were determined in triplicate and repeated to confirm activity [61].

\section{Anticancer activity assay}

Human cancer cell line MG63 (osteosarcoma) was purchased from Bon Yakhteh Company, Tehran, Iran. Cells were cultured at $37^{\circ} \mathrm{C}$, and $5 \% \mathrm{CO}_{2}$ in Dulbecco's Modified Eagle Medium/Nutrient Mixture F-12 (DMEM-F12, Gibco, USA) supplemented with $10 \%$ fetal bovine serum (FBS, Gibco, USA) and $1 \%$ penicillin/streptomycin. At $85 \%$ confluence, the cells were harvested using $0.25 \%$ trypsin-EDTA. Then cells were seeded at $5 \times 10^{4}$ density in each well containing $100 \mu$ DMEM-F12 medium supplemented with $10 \%$ 
FBS in a 96-well plate and allowed to attach for $24 \mathrm{~h}$ before treatment. Cells were treated with various doses of chemicals ( 0.3 to $5 \mathrm{mg}$ ) dispersed in double distilled water. The identical volume of solvent was used as a control. The effects of the chemical agents on cell proliferation were detected by MTT (3-(4,5dimethylthiazolyl-2)-2,5-diphenyltetrazolium bromide) assay. After $24 \mathrm{~h}$ incubation, MTT solution (5 $\mu \mathrm{g} / \mathrm{ml}$ ) was added to each well, and the plates were incubated in a $\mathrm{CO}_{2}$ incubator for $3 \mathrm{~h}$. The media was removed, and DMSO was added to each well to solubilize the formazan crystals. The optical density (OD) of each well was measured $(570 \mathrm{~nm}$ ) using a microplate reader (infinite F50, TECAN, Austria), and the growth inhibition was calculated [62]. Cytotoxicity is shown as the concentration of a compound inhibiting cell growth by $50 \%\left(\mathrm{IC}_{50}\right)$. All tests were carried out three times, and the mean values were recorded.

\section{Antioxidant activity}

The investigation on the antioxidant properties of chemicals was performed using the DPPH assay at six different concentrations $(0.15,0.30,0.625,1.25,2.5$, and $5 \mathrm{mg} / \mathrm{ml})$. Consequently, the antioxidant activity for the catalyst at the concentration of $5 \mathrm{mg} / \mathrm{ml}$ was measured as $80 \%$. Result showed that the antioxidant activity was significantly associated with that compound concentration (Figure 11).

\section{Antibacterial activity}

The inhibition growth (\%) of the benzoguanamine-based nickel complex (nano-catalyst) were investigated at the highest concentration $(5 \mathrm{mg} / \mathrm{ml})$ against the two tested bacteria (E. coli (-) and S. aureus (+)) which was $94 \%$ and $81 \%$, respectively.

Results showed that the catalyst could impair the growth of both the gram-positive and the gramnegative bacteria in all tested concentrations. Owing to the effect of lipopolysaccharide and other structural features of gram-negative bacterial cell walls, these pathogens are usually more resistant to antibacterial compounds. Antibacterial assay on catalyst determined an inhibitory effect at the concentration of $0.65 \mathrm{mg} / \mathrm{ml}$ and higher. Noteworthy to mention, inhibitory activity of catalyst on $S$. aureus was stronger than that on E. coli (Figure 12).

\section{Anticancer activity}

The present study investigated the anticancer activity of the catalyst against the MG63 cell line. The ratio of cell viability under catalyst treatment has shown a considerable decrease compared to Cisplatin as the positive control confirming its anticancer property. The $\mathrm{IC}_{50}$ value determined the growth inhibition of cancer cells, indicating that compound concentration was associated with the half inhibition of cancer cell growth (Figures 13 and 14).

\section{Conclusions}


In summary, a new heterogeneous magnetic nano-catalyst was synthesized, characterized and its formation was confirmed by several methods, including FT-IR spectroscopy, EDX spectroscopy, elemental mapping, XRD analysis, SEM, TG-DTA, VSM and BET. The catalytic performance of this catalyst was investigated in preparation of benzimidazoles derivatives from the reaction of PhenDA with various aldehydes under mild reaction conditions with good to high yield in short reaction times.

\section{Declarations}

\section{Conflicts of interest}

There are no conflicts of interest to be declared.

\section{Acknowledgements}

The authors are grateful to the Bu-Ali Sina University for the support of this work.

\section{Supporting information}

Supporting information for this article is available online at ...

\section{References}

1. Sethi P, Bansal Y, Bansal G (2017) Synthesis and PASS-assisted evaluation of coumarinbenzimidazole derivatives as potential anti-inflammatory and anthelmintic agents. Med Chem Res 27:61-71

2. Nakano H, Inoue T, Kawasaki N, Miyataka H, Matsumoto H, Taguchi T, Inagaki N, Nagai H, Satoh T (2000) Synthesis and biological activities of novel antiallergic agents with 5-Lipoxygenase inhibiting action. Bioorg Med Chem 8:373-380

3. Cheong JE, Zaffagni M, Chung I, Xu Y, Wang Y, Jernigan FE, Zetter BR, Sun L (2018) Synthesis and anticancer activity of novel water soluble benzimidazole carbamates. Eur J Med Chem 144:372-385

4. Rashid M, Husain A, Mishra R (2012) Synthesis of benzimidazoles bearing oxadiazole nucleus as anticancer agents. Eur J Med Chem 54:855-866

5. Ito Y, Shibata K, Hongo A, Kinoshita M (1998) Ecabet sodium, a locally acting antiulcer drug, inhibits urease activity of Helicobacter pylori. Eur J Pharmacol 345:193-198

6. Gellis A, Kovacic H, Boufatah N, Vanelle P (2008) Synthesis and cytotoxicity evaluation of some benzimidazole-4,7-diones as bioreductive anticancer agents. Eur J Med Chem 43:1858-1864

7. Bansal Y, Silakari O (2012) The therapeutic journey of benzimidazoles: A review. Bioorg Med Chem 20:6208-6236

8. Chandrika NT, Shrestha SK, Ranjan N, Sharma A, Arya DP, Garneau-Tsodikova S (2018) New application of neomycin $\beta$-bisbenzimidazole hybrids as antifungal agents. ACS Infect Dis 4:196-207 
9. Chen G, Liu Z, Zhang Y, Shan X, Jiang L, Zhao Y, He W, Feng Z, Yang S, Liang G (2013) Synthesis and anti-inflammatory evaluation of novel benzimidazole and imidazopyridine derivatives. ACS Med Chem Lett 4:69-74

10. Ndakala AJ, Gessner RK, Gitari PW, October N, White KL, Hudson A, Fakorede F, Shackleford DM, Kaiser M, Yeates C (2011) Antimalarial pyrido[1,2-a] benzimidazoles. J Med Chem 54:4581-4589

11. Demirci S, Basoglu S, Bozdereci A, Demirbas N (2013) Preparation and antimicrobial activity evaluation of some new bi- and tri-heterocyclic azoles. Med Chem Res 22:4939-4945

12. Zhang HZ, He SC, Peng YJ, Zhang HJ, Gopala L, Tangadanchu VKR, Gan LL, Zhou CH (2017) Design, synthesis and antimicrobial evaluation of novel benzimidazole-incorporated sulfonamide analogues. Eur J Med Chem 136:165-183

13. Desai NC, Pandya DD, Kotadiya GM, Desai P (2014) Synthesis, antimicrobial, and cytotoxic activities of novel benzimidazole derivatives bearing cyanopyridine and 4-thiazolidi-none motifs. Med Chem Res 23:3823-3835

14. Tunçbilek M, Kiper T, Altanlar N (2009) Synthesis and in vitro antimicrobial activity of some novel substituted benzimidazole derivatives having potent activity against MRSA. Eur J Med Chem 44:1024-1033

15. Valdez J, Cedillo R, Hernández-Campos A, Yépez L, Hernández-Luis F, Navarrete-Vázquez G, Tapia A, Cortés R, Hernández M, Castillo R (2002) Synthesis and antiparasitic activity of 1H-benzimidazole derivatives. Bioorg Med Chem Lett 12:2221-2224

16. Desai NC, Shihory NR, Kotadiya GM, Desai P (2014) Synthesis, antibacterial and antitubercular activities of benzimidazole bearing substituted 2-pyridone motifs. Eur J Med Chem 82:480-489

17. Eevic KS, Kralj M, Ester K, Sabol I, Grce M, Pavelic KI, Zamola GK (2007) Synthesis, antiviral and antitumor activity of 2-substituted-5-amidino-benzimidazoles. Bioorg Med Chem 15:4419-4426

18. Tonelli M, Novelli F, Tasso B, Vazzana I, Sparatore A, Boido V, Sparatore F, La Colla P, Sanna G, Giliberti G (2014) Antiviral activity of benzimidazole derivatives. III. Novel anti-CVB-5, anti-RSV and anti-Sb-1 agents. Bioorg Med Chem 22:4893-4909

19. Boiani M, Gonzalez M (2005) Imidazole and benzimidazole derivatives as chemotherapeutic agents. Eur J Med Chem 5:409-424

20. Roth T, Morningstar ML, Boyer PL, Hughes SH, Buckheit RWJ, Michejda CJ (1997) Synthesis and biological activity of novel nonnucleoside inhibitors of HIV-1 reverse transcriptase. 2-Aryl-substituted benzimidazoles. J Med Chem 40:4199-4207

21. Kim JS, Gatto B, Yu C, Liu A, Liu LF, La V (1996) Substituted 2,5'-bi-1H-benzimidazoles:

Topoisomerase I inhibition and cytotoxicity. J Med Chem 39:992-998

22. Anastassova N, Argirova M, Yancheva D, Aluani D, Tzankova V, Hristova-Avakumova N, Hadjimitova V. In vitro assessment of the neuroprotective and antioxidant properties of new benzimidazole derivatives as potential drug candidates for the treatment of Parkinson's disease. Proceedings. 2019;22:54-56 
23. Benavent L, Baeza A, Freckleton M (2018) Chiral 2-aminobenzimidazole as bifunctional catalyst in the asymmetric electrophilic amination of unprotected 3-substituted oxindoles. Molecules 23:13741383

24. Jin-Feng X, Jian XL, Guang Z, Jing PH, Jin YL, Xiao YC, Zhao YW (2014) Benzimidazole derivatives: Selective fluorescent chemo-sensor for the picogram detection of picric acid. J Org Chem 79:1161911630

25. Curkovic HO, Stupnisek-Lisac E, Takenouti H (2010) The influence of pH value on the efficiency of imidazole-based corrosion inhibitors of copper. Corrosion Sci 52:398-405

26. Madkour LH, Elshamy IH (2016) Experimental and computational studies on the inhibition performances of benzimidazole and its derivatives for the corrosion of copper in nitric acid. Int $J$ Integrated Care 7:195-221

27. Desiraju GR (1995) Supramolecular synthons in crystal engineering: A new organic synthesis. Angew Chem Int Ed 34:2311-2327

28. Atar A, Taspinar O, Hanft S, Goldfuss B, Schmalz HG, Griesbeck AG (2019) Hydrogen peroxide sensors based on fluorescence quenching of the 2aminobenz-imidazole fluorophore. $\mathrm{J}$ Org Chem 84:15972-15977

29. Hanan EJ, Chan BK, Estrada AA, Shore DG, Lyssikatos JP (2010) Mild and general one-pot reduction and cyclization of aromatic and heteroaromatic 2-nitro-amines to bicyclic $2 \mathrm{H}$-imidazoles. Synlett 18:2759-2764

30. Nale DB, Bhanage BM (2015) N-Substituted formamides as C1-sources for the synthesis of benzimidazole and benzothiazole derivatives by using zinc catalysts. Synlett 26:2831-2834

31. Zhu $X$, Zhang F, Kuang D, Deng G, Yang $Y$, Yu J, Liang $Y(2020) K_{2} S$ as sulfur source and DMSO as carbon source for the synthesis of 2unsubstituted benzothiazoles. Org Lett 22:3789-3793

32. Mahesh D, Sadhu P, Punniyamurthy T (2015) Copper(I)-catalyzed regioselective amination of N-aryl imines using TMSN ${ }_{3}$ and TBHP: A route to substituted benzimid-azoles. J Org Chem 80:1644-1650

33. Mahesh D, Sadhu P, Punniyamurthy T (2016) Copper(II)-catalyzed oxidative cross-coupling of anilines, primary alkyl amines and sodium azide using TBHP: A route to 2-substituted benzimidazoles. J Org Chem 81:3227-3234

34. Wang Z, Song T, Yang Y (2019) Additive- and oxidant-free expedient synthesis of benzimidazoles catalyzed by cobalt nanocomposites on N-doped carbon. Synlett 30:319-324

35. Das K, Mondal A, Srimani D (2018) Selective synthesis of 2substituted and 1,2-di-substituted benzimidazoles directly from aromatic diamines and alcohols catalyzed by molecularly defined nonphosphine manganese(I) complex. J Org Chem 83:9553-9560

36. Hu Z, Zhao T, Wang M, Wu J, Yu W, Chang J (2017) $\mathrm{I}_{2}$-mediated intramolecular C-H amidation for the synthesis of N-substituted benzimidazoles. J Org Chem 82:3152-3158

37. Zhang R, Qin Y, Zhang L, Luo S (2017) Oxidative synthesis of benzimidazoles, quinoxalines, and benzoxazoles from primary amines by orthoquinone catalysis. Org Lett 19:5629-5632 
38. Nguyen TB, Ermolenko L, Dean WA, Al-Mourabit A (2012) Benzazoles from aliphatic amines and Oamino/mercaptan/hydroxyanilines: elemental sulfur as a highly efficient and traceless oxidizing agent. Org Lett 14:5948-5951

39. Nguyen TB, Ermolenko L, Al-Mourabit A (2015) Sodium Sulfide: A sustainable solution for unbalanced redox condensation reaction between 0 -nitroanilines and alcohols catalyzed by an ironsulfur system. Synthesis 47:1741-1748

40. Nguyen TB, Le Bescont J, Ermolenko L, Al-Mourabit A (2013) Cobalt- and iron-catalyzed redox condensation of Osubstituted nitrobenzenes with alkylamines: A step- and redox-economical synthesis of diazaheterocycles. Org Lett 15:6218-6221

41. Mayo M, Yu X, Zhou X, Feng X, Yamamoto Y, Bao M (2014) Convenient synthesis of benzothiazoles and benzimidazoles through Brønsted acid catalyzed cyclization of 2amino thiophenols/anilines with ßdiketones. Org Lett 16:764-767

42. Bastug G, Eviolitte C, Markó IE (2012) Functionalized orthoesters as powerful building blocks for the efficient preparation of heteroaromatic bicycles. Org Lett 14:3502-3505

43. Hati S, Dutta PK, Dutta S, Munshi P, Sen S (2016) Accessing benzimidazoles via a ring distortion strategy: An oxone mediated tandem reaction of 2aminobenzyl-amines. Org Lett 18:3090-3093

44. Maleki A (2014) Synthesis of imidazo[1,2-a]pyridines using $\mathrm{Fe}_{3} \mathrm{O}_{4} @ \mathrm{SiO}_{2}$ as an efficient nanomagnetic catalyst via a one-pot multicomponent reaction. Helv Chim Acta 97:587-593

45. Maleki A, Ghamari N, Kamalzare M (2014) Chitosan-supported $\mathrm{Fe}_{3} \mathrm{O}_{4}$ nanoparticles: a magnetically recyclable heterogeneous nano-catalyst for the syntheses of multi-functional benzimidazoles and benzodiazepines. RSC Adv 4:9416-9423

46. Maleki A, Aghaei M, Ghamari N (2015) Synthesis of benzimidazolo[2,3- $b$ ]quinazolinone derivatives via a one-pot multicomponent reaction promoted by a chitosan-based composite magnetic nanocatalyst. Chem Lett 44:259-261

47. Maleki A, Hajizadeh Z, Abbasi H (2018) Surface modification of graphene oxide by citric acid and its application as a heterogeneous nanocatalyst in organic condensation reaction. Carbon Lett 27:4249

48. Maleki A, Rahimi J (2018) Synthesis of dihydroquinazolinone and octahydroquin- azolinone and benzimidazoloquinazolinone derivatives catalyzed by an efficient magnetically recoverable GObased nanocomposite. J Porous Mater 25:1789-1796

49. Firouzabadi H, Jafari AA (2005) Heteropoly acids, their salts and polyoxometalates as heterogenous, efficient and eco-friendly catalysts in organic reactions: some recent advances. J Iran Chem Soc 2:85-114

50. Rostamnia S, Doustkhah E (2016) Covalently bonded zwitterionic sulfamic acid onto the SBA-15 $\left(\mathrm{SBA}-15 / \mathrm{PrEn}-\mathrm{NHSO}_{3} \mathrm{H}\right.$ ) reveals good Bronsted acidity behavior and catalytic activity in Nformylation of amines. J Mol Catal A-Chem 411:317-324 
51. Rostamnia S, Doustkhah E. Increased (2015) SBA-15- $\mathrm{SO}_{3} \mathrm{H}$ Catalytic activity through hydrophilic/hydrophobic fluoroalkyl-chained alcohols (RFOH/SBA-15-Pr-SO $\left.{ }_{3} \mathrm{H}\right)$. Synlett 10:13451347

52. Zolfigol MA, Khakyzadeh V, Moosavi-Zare AR, Rostami A, Zare A, Iranpoor N, Beyzavie MH, Luque R (2013) A highly stable and active magnetically separable Pd nanocatalyst in aqueous phase heterogeneously catalyzed couplings. Green Chem 15:2132-2140

53. Sun Y, Duan L, Guo Z, DuanMu Y, Ma M, Xu L, Zhang Y, Gu N (2005) An improved way to prepare superparamagnetic magnetite-silica core-shell nanoparticles for possible biological application. $J$ Magn Magn Mater 285:65-70

54. Habibi D, Heydari S, Afsharfarnia M, Rostami Z (2017) A versatile synthesis of arylaminotetrazoles by a magnetic Fe@Phendiol@Mn nano-particle catalyst and its theoretical studies. Appl Organomet Chem 31:e3826

55. Habibi D, Heydari S, Faraji A, Keypour H, Mahmoudabadi M (2018) A green and facile approach for the synthesis of $\mathrm{N}$-monosubstituted ureas in water: Pd catalyzed reaction of arylcyanamides (an unexpected behavior of electron withdrawing groups). Polyhedron 151:520-529

56. Wang P, Wang X, Yu S, Zou Y, Wang J, Chen Z, Alharbi NS, Alsaedi A, Hayat T, Chen Y, Wang X (2016) Silica coated $\mathrm{Fe}_{3} \mathrm{O}_{4}$ magnetic nanospheres for high removal of organic pollutants from wastewater. Chem Eng J 306:280-288

57. Aghayee M, Zolfigol MA, Keypour H, Yarie M, Mohammadi L (2016) Synthesis and characterization of a novel magnetic nano-palladium Schiff base complex: application in cross-coupling reactions. Appl Organomet Chem 30:612-618

58. Ariannezhad M, Habibi D, Heydari S (2019) Copper nanoparticles: A capable and versatile catalyst for the synthesis of diverse 1-phenyl-1H-tetrazoles from amino acids. Polyhedron 160:170-179

59. Ribeiro AB, Bolzani V, Yoshida S, Santos M, Eberlin LS, Silva MN (2005) DHS. A new neolignan and antioxidant phenols from Nectandra grandiflora. J Braz Chem Soc 16:526-530

60. Khatua S, Acharya K (2021) Antioxidative and antibacterial ethanol extract from a Neglected indigenous myco-food suppresses Hep3B proliferation by regulating ROS-driven intrinsic mitochondrial pathway. Biointerface Res Appl Chem 11:11202-11220

61. Bothon FTD, Debiton E, Avlessi F, Forestier Ch, Teulade JC, Sohounhloue DKC (2013) In vitro biological effects of two anti-diabetic medicinal plants used in Benin as folk medicine. BMC Complement Altern Med 13:1-8

62. Bahuguna A, Khan I, Bajpai VK (2017) 0 Kang SCh. MTT assay to evaluate the cytotoxic potential of a drug. Bangladesh J Pharmacol 12:115-118

\section{Tables}

Due to technical limitations, table 3 is only available as a download in the Supplemental Files section. 
Figures

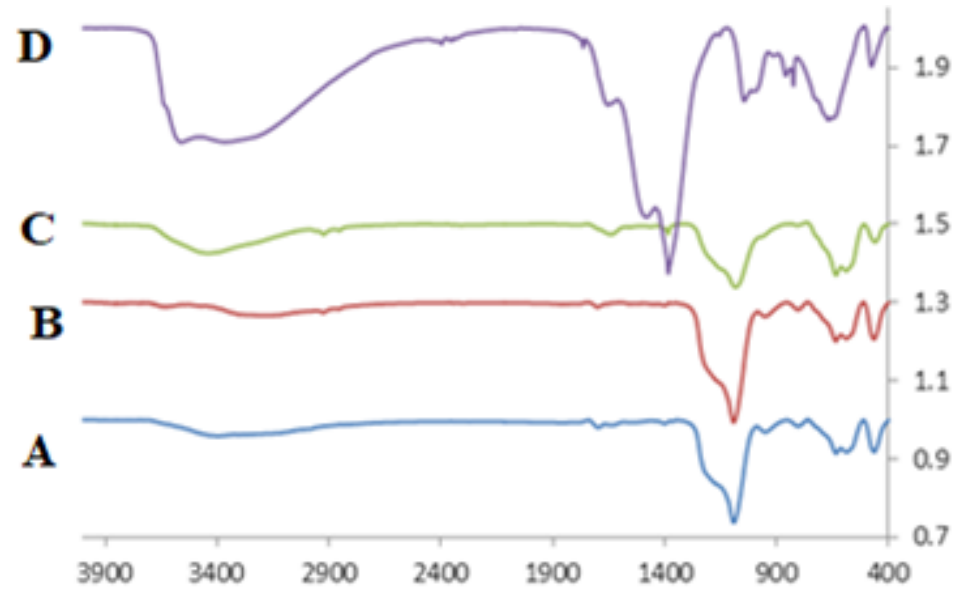

\section{Figure 1}

The FT-IR spectra of A), B), C) and D) Fe304@SiO2@CPTMS@BGA@Ni.

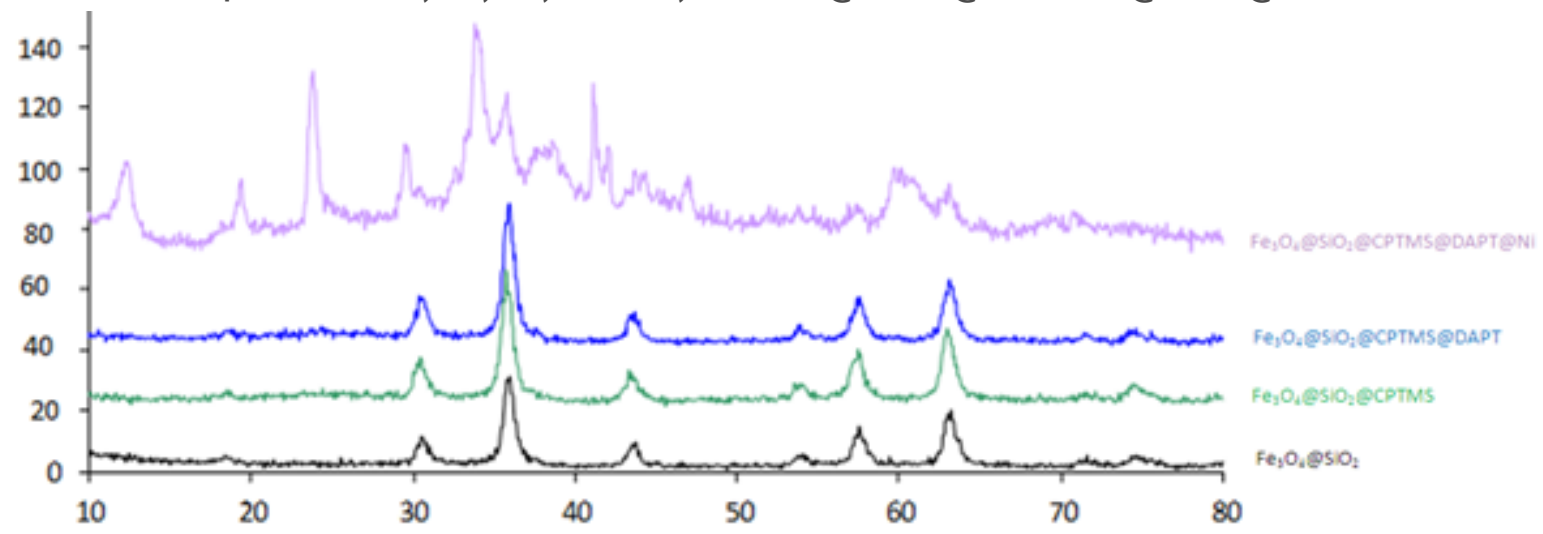

Figure 2

The XRD patterns of $A, B, C$ and $D$.

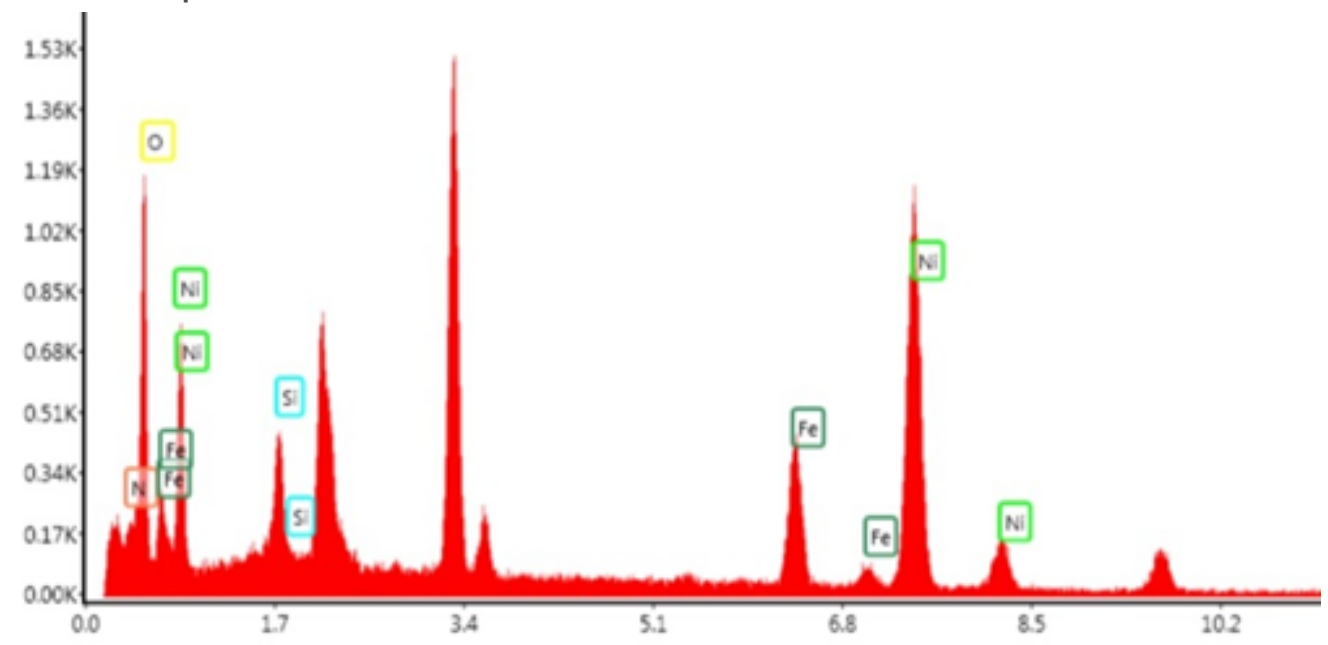

Figure 3 
The EDX analysis of the Ni-supported nano-catalyst.
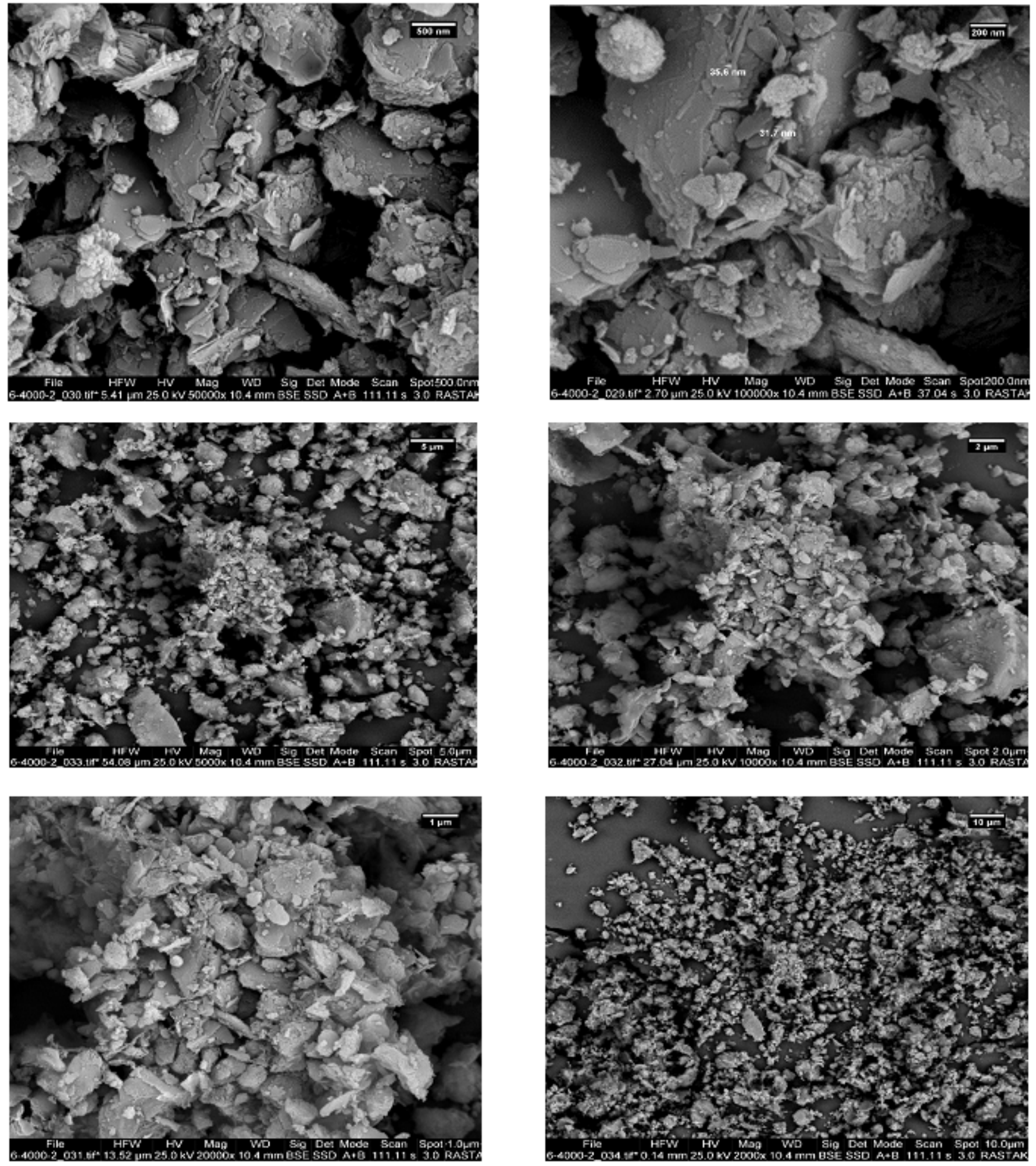

Figure 4

The SEM images of the Ni-supported nano-catalyst. 


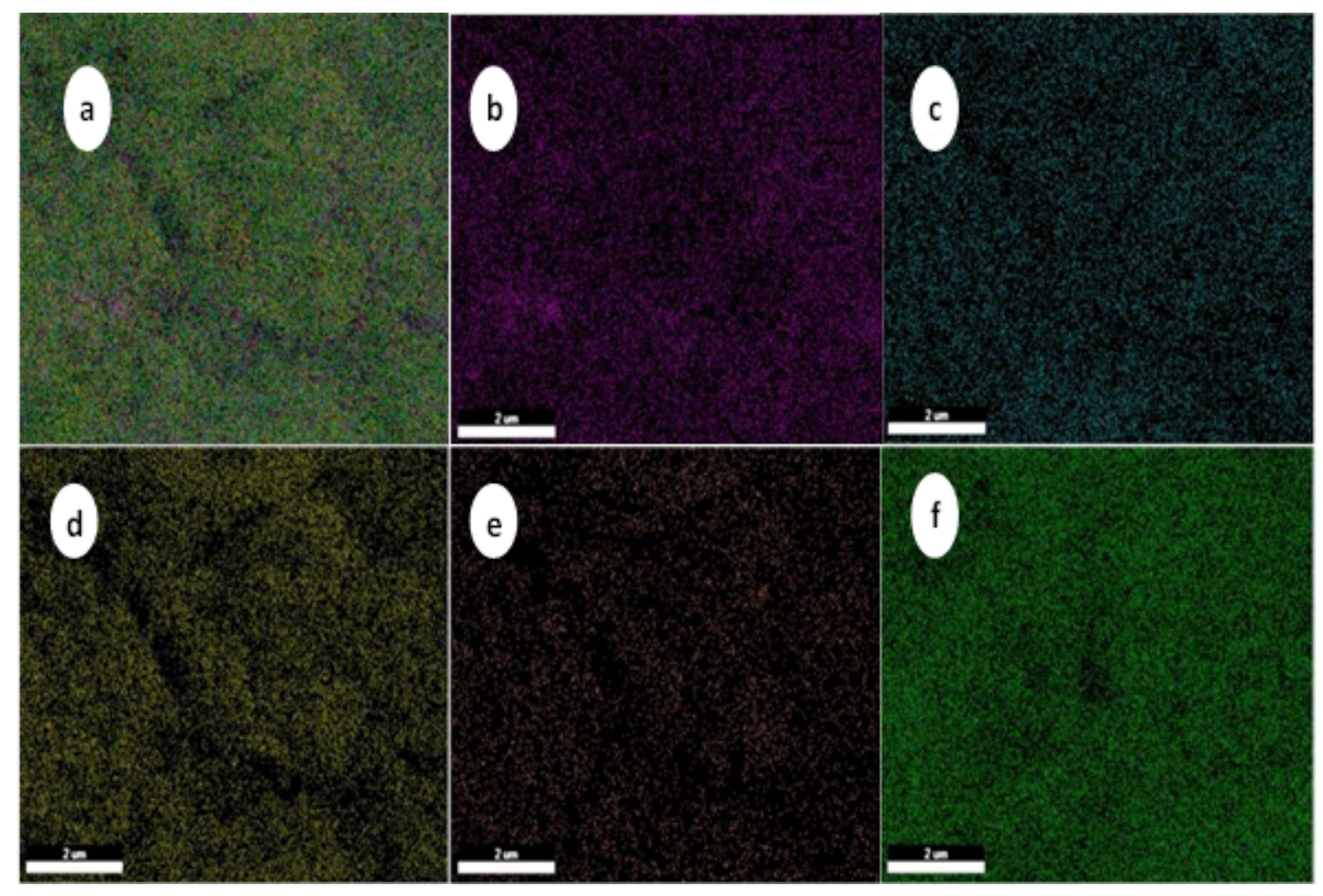

\section{Figure 5}

The elemental mapping images of the overlapping elements (a), iron (b), silicon (c), oxygen (d), nitrogen (e) and nickel (f) in the Ni-supported nano-catalyst.

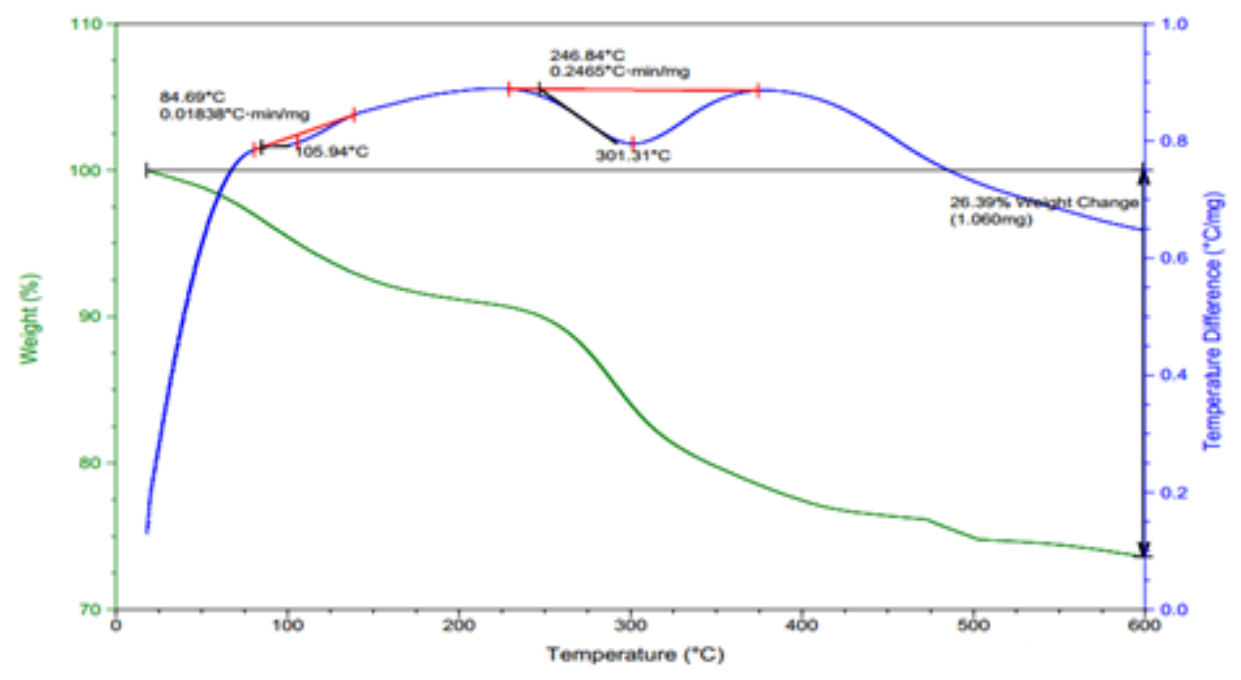

Figure 6

The TGA-DTA patterns of the Ni-supported nano-catalyst. 


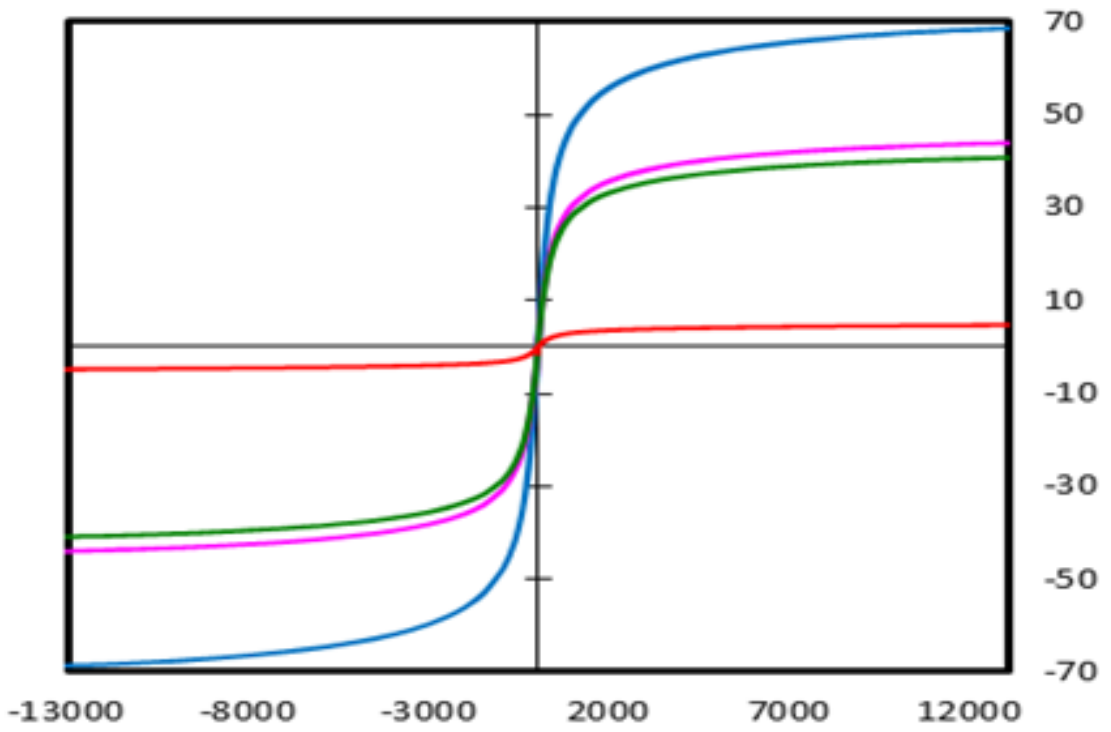

Figure 7

The VSM analyses of A, B, C and D.

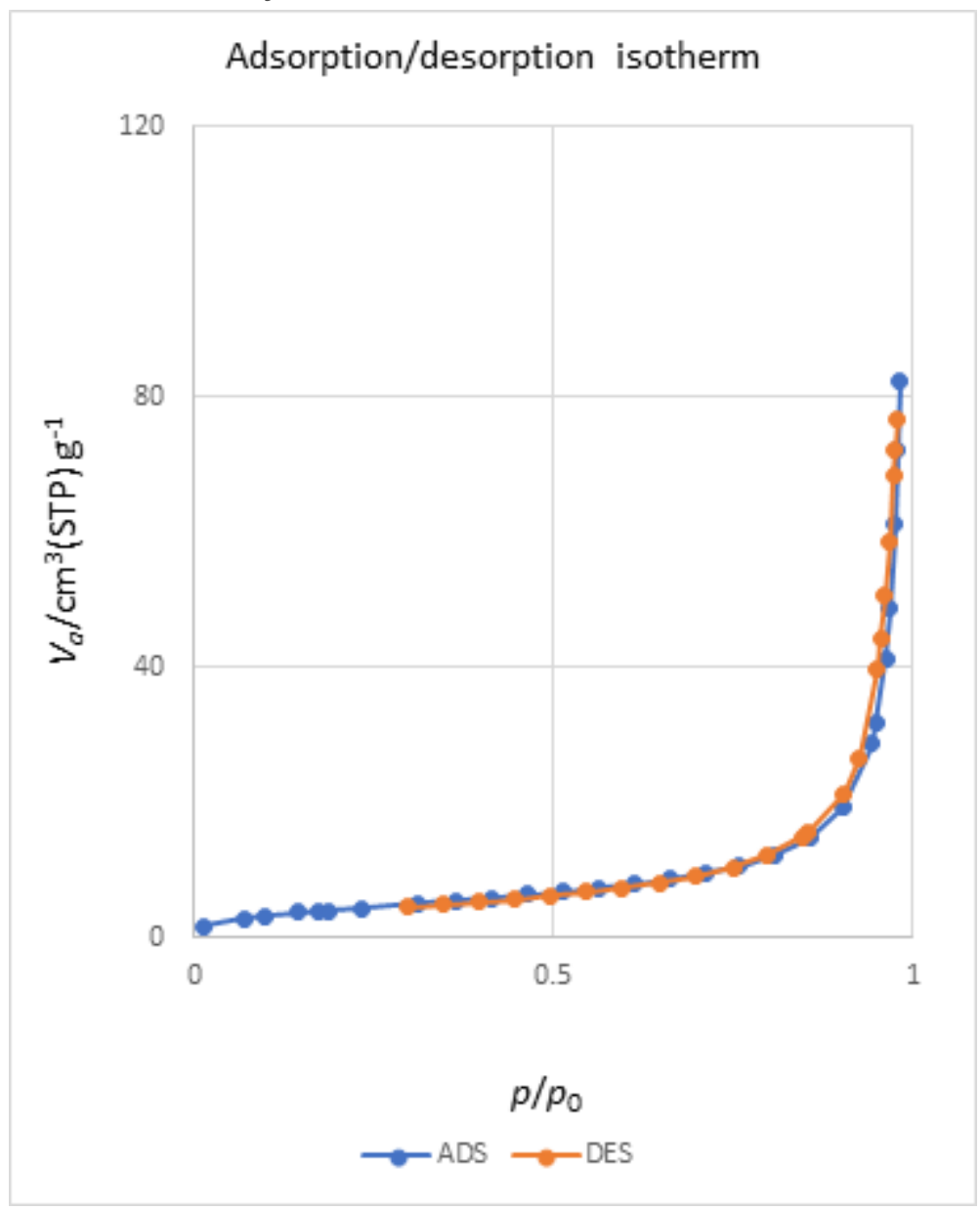

Figure 8

The nitrogen adsorption-desorption curve (BET) of the Ni-supported complex. 


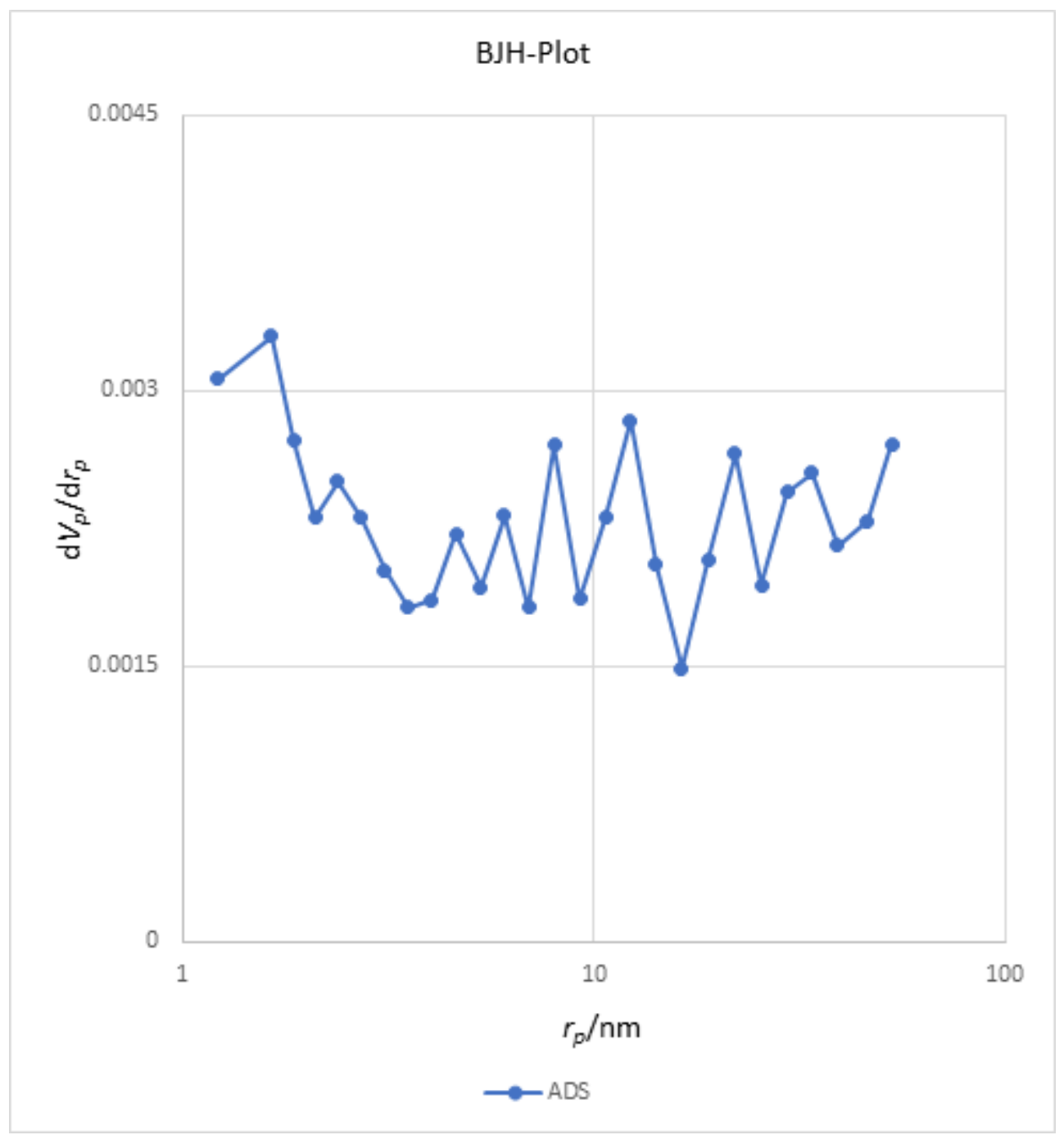

Figure 9

The BJH adsorption curve of the Ni-supported complex.

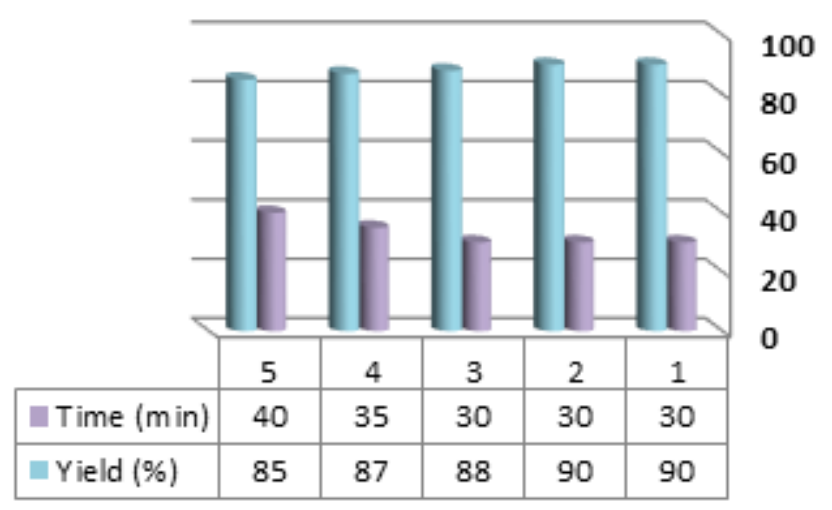

Figure 10

Reusability of the Ni-supported nano-catalyst in five-consecutive reaction runs. 


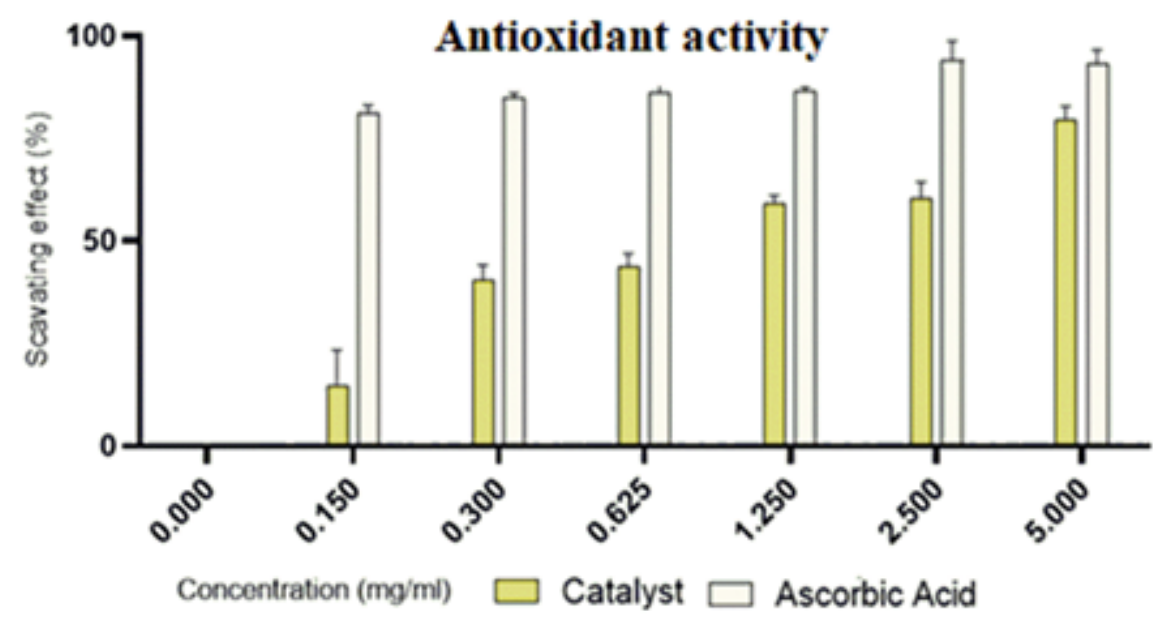

Figure 11

DPPH radical scavenging activity (\%) of the catalyst at 6 different concentrations and ascorbic acid as standard. Data are expressed as mean \pm SD. Graphs are representative of independent experiment performed in triplicate.

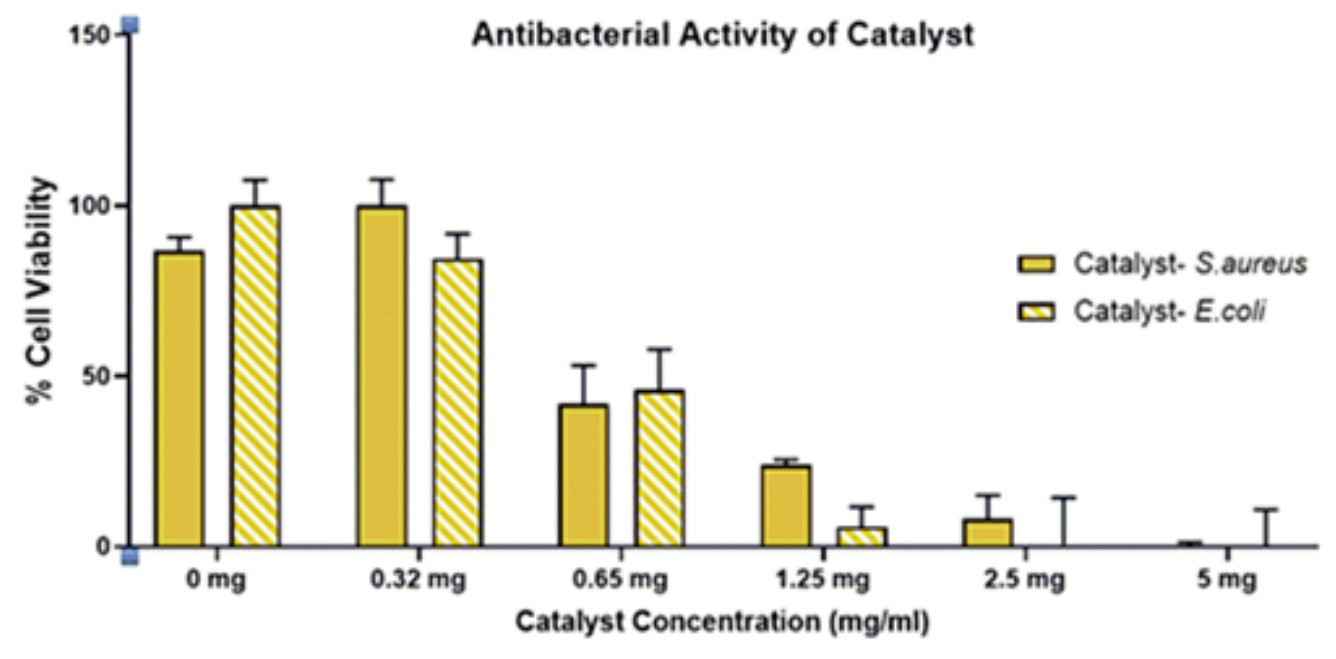

Figure 12

Minimum inhibitory concentration (MIC) of the catalyst $(\mathrm{mg} / \mathrm{ml})$ against 2 ATCC bacteria. The experiment was performed in triplicate and expressed as mean \pm SD. 


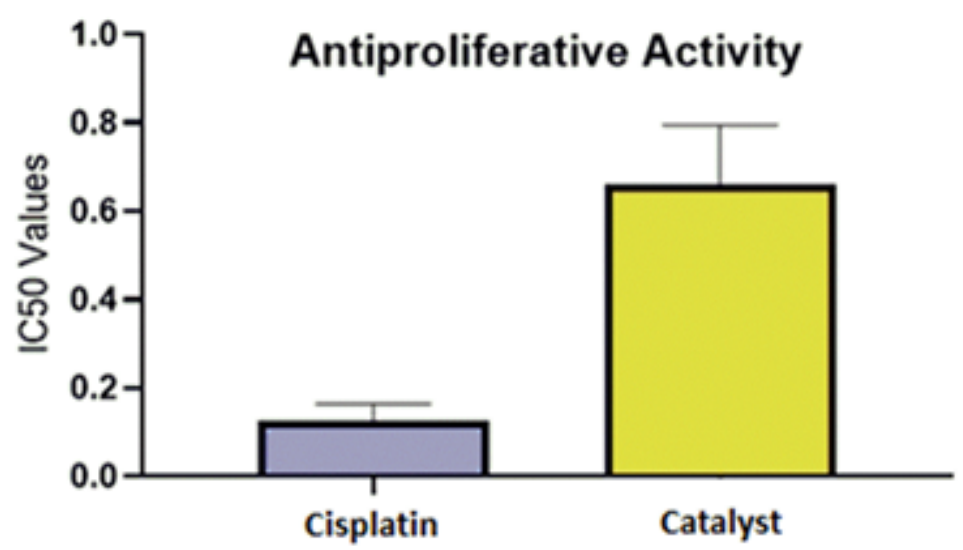

Figure 13

Graphical representation of the antiproliferative activity of the catalyst against MG63 cancer cell line obtained by MTT for indicated concentrations for $24 \mathrm{~h}$. Data are expressed as mean \pm SD. The data were normalized as a function of the mean negative control treatment. Representative graphs of independent experiment performed in triplicate $(P<0.05)$.

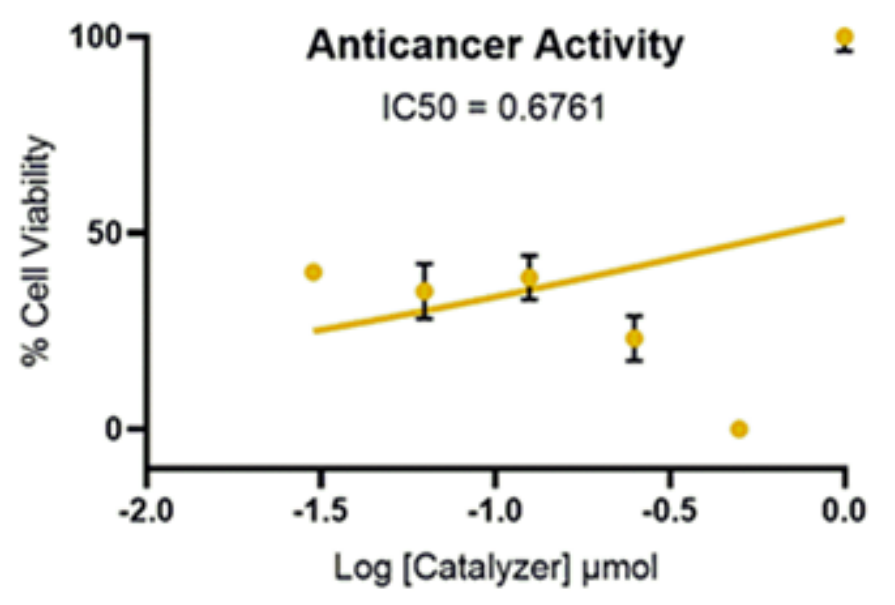

Figure 14

Graphical representation of the antiproliferative activity of the catalyst against MG63 cancer cell line obtained by MTT for indicated concentrations for $24 \mathrm{~h}$. Data are expressed as mean \pm SD. The data were normalized as a function of the mean negative control treatment. Representative graphs of independent experiment performed in triplicate $(P<0.05)$.

\section{Supplementary Files}

This is a list of supplementary files associated with this preprint. Click to download.

- Scheme01.png

- Scheme02.png 
- Scheme03.png

- Table3.docx

- supportinginformation.docx 